\title{
On the structural logic of curriculum system for the optical instrument major
}

Yufeng Yan, Juncen Yan, Yang Li, Lixia Shi

Yufeng Yan, Juncen Yan, Yang Li, Lixia Shi, "On the structural logic of curriculum system for the optical instrument major," Proc. SPIE 10452, 14th Conference on Education and Training in Optics and Photonics: ETOP 2017, 1045234 (16 August 2017); doi: 10.1117/12.2270959

SDIE Event: 14th Conference on Education and Training in Optics and Photonics, ETOP 2017, 2017, Hangzhou, China 


\title{
On the Structural Logic of Curriculum System for the Optical Instrument Major
}

\author{
Yufeng Yan ${ }^{* a}$, Juncen Yan ${ }^{\mathrm{a}}$, Yang $\mathrm{Li}^{\mathrm{a}}$, Lixia Shi $^{\mathrm{a}}$ \\ ${ }^{a}$ Changchun University of Science and Technology, 7089 Weixing Road Changchun, Jilin, 130022
}

\begin{abstract}
The theories of optical instrument are the Interdisciplinary of Optical Engineering and Instrument Science and Technology. The undergraduates should study the knowledge about the optics, precision machine and electronics. The courses such as Theory of Machine, Engineering Optics, even include some courses about Accuracy Analysis of Instrument are offered in the college. There are a lot of correlatives among these courses. This paper focuses on the structural logic of these courses. The order of these courses is researched, The aims of all the courses are clear completely to avoid the same topics to be taught twice in different courses. Therefore, the undergraduates would get the main line of the knowledge, and the professors would teach efficiently.
\end{abstract}

Keywords: optical instrument major, structural logical, curriculum system, order of curriculum system, aims of the course

\section{INTRODUCTION}

The optical instrument design is a major direction for the students of Measuring \& Control Technology and Instrumentations Major, as a traditional major in Changchun university of science and technology (CUST, the original name is Changchun Institute of Optical and Fine Mechanic, CIOM), we maintain the special feature that the optics is combined with fine mechanics during teaching. So, the major direction is the interdisciplinary of optical engineer and instrument science and technology .Therefore, there are two main line be design about the courses, one is the optical courses include the Physical optics, Applied Optics, Photoelectric Detection Technology, Optical Measurement, Optical Design and CAD etc., and another main line is the fine mechanical courses such as Theory of Engineering Drawing ,Machine and Mechanisms, Fundamentals of Interchangeability and Measurement Technology ,Error Theory and Data Processing, Instrument Elements Designing, Photoelectric Instrument Design, etc.. Furthermore, the courses about electronics and information are offered according to the most general engineering majors. A lot of links consist in these courses, But some student can't understand the undertake relations of them, and some teacher can't clear the aim of the courses, even the same contents are taught twice in different course. For solving the above problems, This paper focuses on the sequence and the structural logic of the curriculum system.

\section{COURSE PLAN}

\subsection{Cultivation Goal}

Almost the cultivation goal of different major can be concluded in the general standards and distinguishing standards. Firstly, the general standards include the requirement such as, the basic knowledge, the ability of independent learning and lifelong learning, the cognition of team spirit and social responsibility. Secondly, the distinguishing standards are the requirement about the specialized knowledge, the specialized skill and the ability to finish the project. ${ }^{[1,2]}$ The system diagram of cultivation goal and courses as Fig.1. The optical instrument design major being introduced in this paper combines the tradition of CIOM with the advantage in optical field, the main distinguishing standards as follows:

(1) Through systematical learning and training, multiform teaching and engineering practice with the program, Graduates can master the theories such as Photoelectric Instrument Design, Intelligent Instrument, Optical Design, Accuracy Analysis of Instrument, Instrument Manufacturing Technique, Optical Instrument Assembly and Adjustment, gain abilities of technology integration and precision instrument design.

* yanyufeng@ cust.edu.cn; phone:+86 43185582250; 
(2) Graduates can design and solve the engineering problems in the field of precision instruments.

(3) Graduates can track the development of new technologies in the field of precision instruments, and to solve complex engineering problems in special environments.

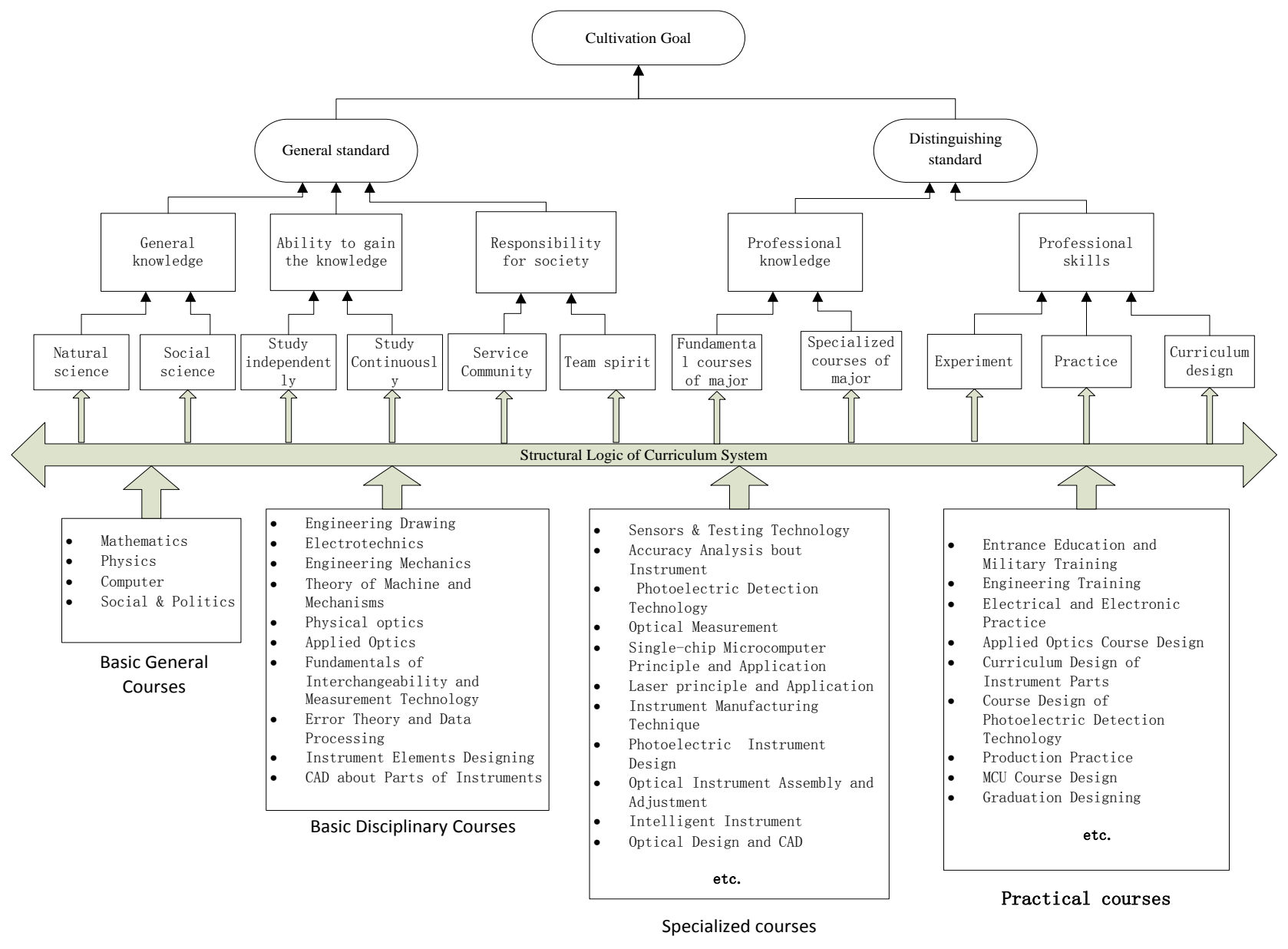

Figure 1. System diagram of cultivation goal and courses

\subsection{The Proportion Relationship of the Courses}

\subsubsection{The quantity compare of all courses}

As shown in Fig.2. There are 16 required basic general courses, furthermore, 3 to 6 quality-oriented education courses should be elected in order to achieve the credit requirement, so the total quantity of the general basic course is about 21 , there are 15 basic disciplinary courses, they are all the required courses, and the quantity of the specialized required courses. 


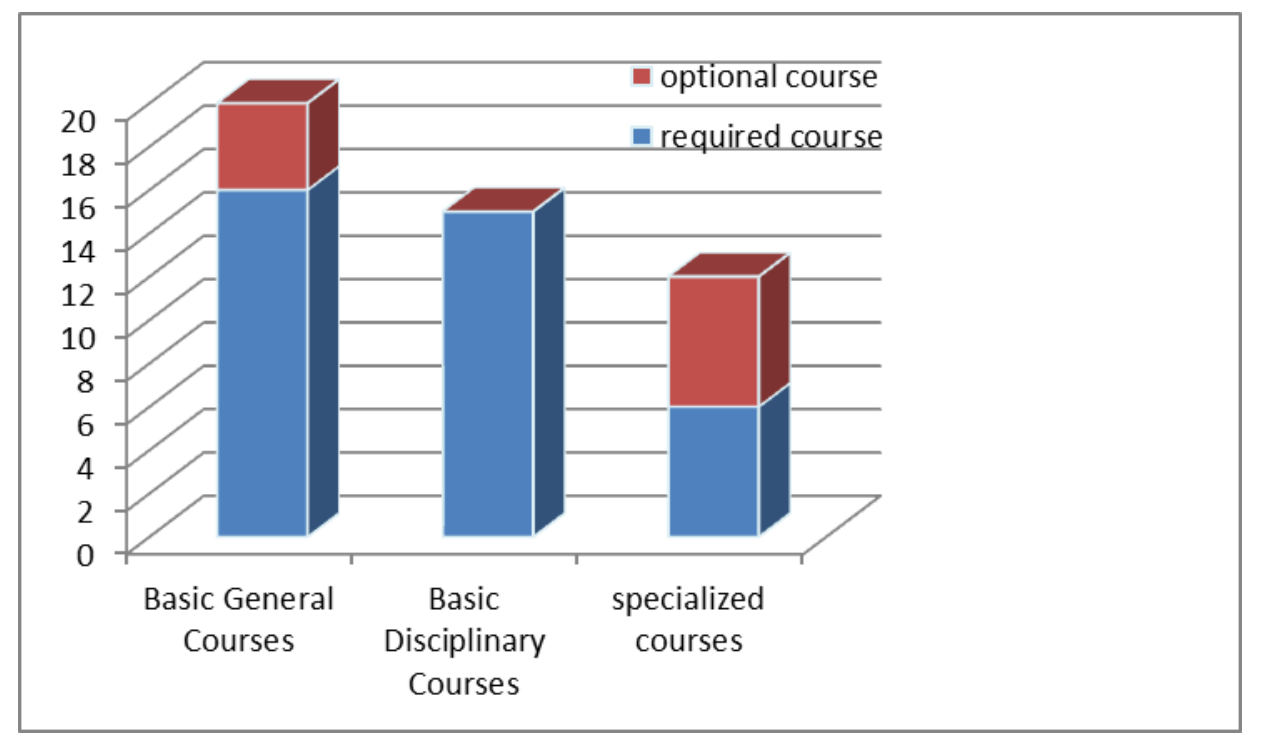

Figure 2. The quantity compare diagram of all courses

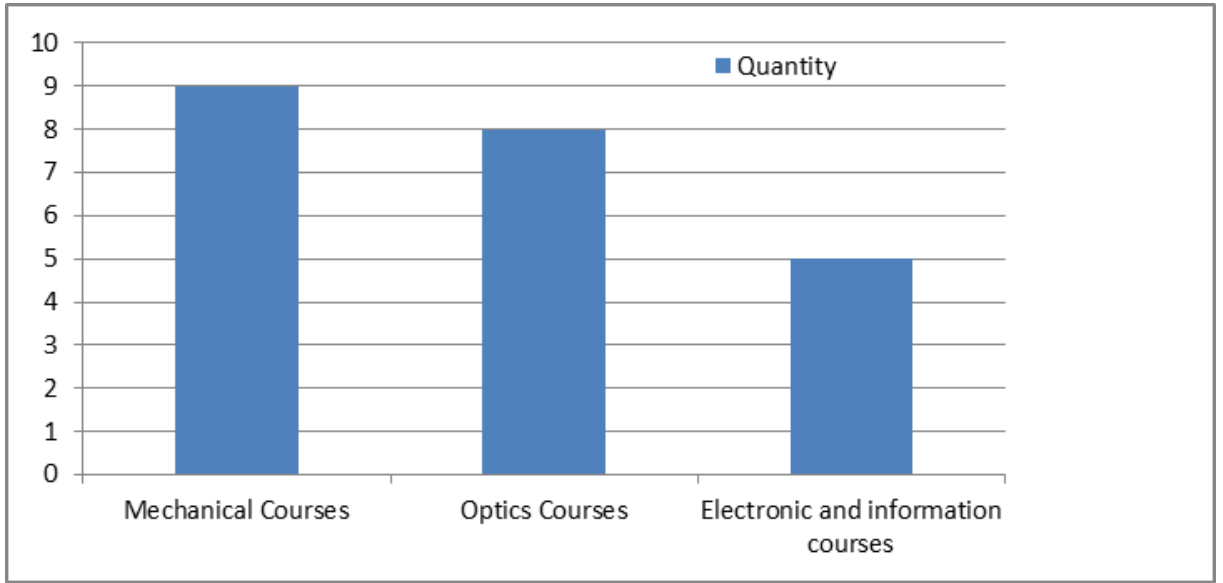

Figure 3. The classification comparison diagram about the quantity of all basic disciplinary courses and specialized courses

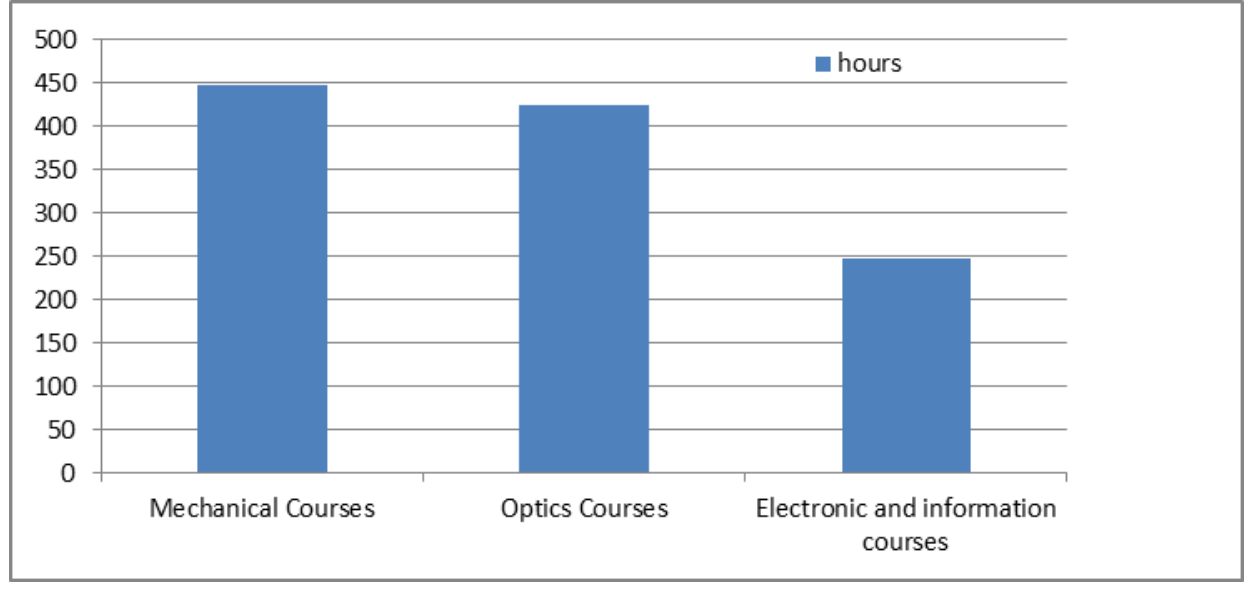

Figure 4. The classification comparison diagram about the class hours of all basic disciplinary courses and specialized courses 
2.2.2 The analysis of basic disciplinary courses and specialized course

Table 1. Courses categories table

\begin{tabular}{|c|c|c|c|c|}
\hline No. & category & name & Hours & Characteristic \\
\hline 1 & \multirow{9}{*}{$\begin{array}{l}\text { Mechanical } \\
\text { Courses }\end{array}$} & Engineering Drawing & 80 & Basic Disciplinary Courses \\
\hline 2 & & Engineering Mechanics & 72 & Basic Disciplinary Courses \\
\hline 3 & & Theory of Machine and Mechanisms & 48 & Basic Disciplinary Courses \\
\hline 4 & & Instrument Manufacturing Technique & 48 & Basic Disciplinary Courses \\
\hline 5 & & Error Theory and Data Processing & 40 & Basic Disciplinary Courses \\
\hline 6 & & $\begin{array}{c}\text { Fundamentals of Interchangeability and } \\
\text { Measurement Technology }\end{array}$ & 40 & Specialized Courses \\
\hline 7 & & Instrument Elements Designing & 56 & Specialized Courses \\
\hline 8 & & CAD about Parts of Instruments & 32 & Specialized Courses \\
\hline 9 & & Accuracy Analysis about Instrument & 32 & Specialized Courses \\
\hline 10 & \multirow{8}{*}{$\begin{array}{l}\text { Optics } \\
\text { Courses }\end{array}$} & Physical optics & 80 & Basic Disciplinary Courses \\
\hline 11 & & Applied Optics & 64 & Basic Disciplinary Courses \\
\hline 12 & & \#Photoelectric Detection Technology & 64 & Specialized Courses \\
\hline 13 & & Optical Measurement & 48 & Specialized Courses \\
\hline 14 & & Laser principle and Application & 40 & Specialized Courses \\
\hline 15 & & *Photoelectric Instrument Design & 40 & Specialized Courses \\
\hline 16 & & $\begin{array}{c}\text { * Optical Instrument Assembly and } \\
\text { Adjustment }\end{array}$ & 40 & Specialized Courses \\
\hline 17 & & Optical Design and CAD & 48 & Specialized Courses \\
\hline 18 & \multirow{5}{*}{$\begin{array}{l}\text { Electronic } \\
\text { and } \\
\text { information } \\
\text { courses }\end{array}$} & Electrotechnics & 48 & Basic Disciplinary Courses \\
\hline 19 & & Electronic Technique & 56 & Basic Disciplinary Courses \\
\hline 20 & & Foundation of Control Engineering & 48 & Basic Disciplinary Courses \\
\hline 21 & & Sensors \& Testing Technology & 48 & Specialized Courses \\
\hline 22 & & $\begin{array}{c}\text { Single-chip Microcomputer Principle and } \\
\text { Application }\end{array}$ & 48 & Specialized Courses \\
\hline
\end{tabular}

The basic disciplinary courses and specialized course are the important reflections of realizing the cultivation goal. 22 courses include the disciplinary courses and specialized course are required for the student graduating. They can be classified mechanical courses, optics courses and electronic and information courses. The Fig.2 shows the courses' quantity of different categories, and the Fig.3 shows the courses' class hours of different categories. It is almost inevitable that some course belong to two even all three categories, so we list these courses in the Tab.1,the "\#” in front of the course's name mean that the course is belong to the optics and electronic and information at the same time, the “*”mean that the course belong to the optics and mechanical. From the quantity and class hours, we can find the optics and mechanical courses is the main component.

There are 9 Mechanical Courses, the Error Theory and Data Processing and Accuracy Analysis about Instrument are classified into this type because that they are the leading courses of instrument accuracy and error analysis. Among the 8 optics courses, Photoelectric Detection Technology belongs to the optics and electronic and information, the main content of "Photoelectric Instrument Design" and "Optical Instrument Assembly and Adjustment" are about the fine mechanic, the knowledge about optical instrument design is taught in the two courses, so they belong to the optics and 
mechanical. It can be concluded that the theory and knowledge of optics is the characteristic of the major.

\section{THE SEQUENCE OF COURSES}

About the sequence of courses, we consider the way backward from the target, which is start from the last specialized courses or practical training, the leading courses for them are researched, all the needed courses are arranged until the public basic course step by step. ${ }^{[3]}$ The cultivation goals are considered mainly during the curriculum are designed. The courses' sequence in all semesters is shown in Tab. 2, the table does not list the basic general courses which are set up in most colleges and universities in China, such as Ideological and Political Education, Foreign Language, P.E., and modern history of China.

Table 2. courses arrangement and semesters(not included Ideological and Political Education, Foreign Language, P.E.)

\begin{tabular}{|c|c|c|c|c|}
\hline Session & Characteristic & Name of courses & $\begin{array}{c}\text { Quantity of } \\
\text { courses }\end{array}$ & $\begin{array}{l}\text { Quantity } \\
\text { of weeks }\end{array}$ \\
\hline 8 & theoretical courses & Graduation Designing & 1 & 16 \\
\hline \multirow[b]{2}{*}{7} & theoretical courses & $\begin{array}{l}\text { Photoelectric Instrument Design, Optical Instrument Assembly and } \\
\text { Adjustment, Intelligent Instrument, Laser principle and Application }\end{array}$ & 4 & \multirow[b]{2}{*}{18} \\
\hline & Practical courses & $\begin{array}{l}\text { Course Design of Photoelectric Detection Technology, Production } \\
\text { Practice, MCU Course Design, Objective Knowledge Department of } \\
\text { Measurement \& Control Technology and Instruments, }\end{array}$ & 4 & \\
\hline \multirow[t]{2}{*}{6} & theoretical courses & $\begin{array}{l}\text { Instrument Elements Designing, CAD about Parts of Instruments, Accuracy } \\
\text { Analysis about Instrument, Photoelectric Detection Technology, Single-chip } \\
\text { Microcomputer Principle and Application, Optical Measurement }\end{array}$ & 7 & \multirow[t]{2}{*}{19} \\
\hline & Practical courses & Curriculum Design of Instrument Parts & 1 & \\
\hline \multirow[t]{2}{*}{5} & theoretical courses & $\begin{array}{l}\text { Applied Optics, Fundamentals of Interchangeability and Measurement } \\
\text { Technology, Foundation of Control Engineering, Error Theory and Data } \\
\text { Processing, Instrument Manufacturing Technique, Sensors \& Testing } \\
\text { Technology }\end{array}$ & 5 & \multirow[t]{2}{*}{18} \\
\hline & Practical courses & Applied Optics Course Design & 1 & \\
\hline \multirow[t]{2}{*}{4} & theoretical courses & $\begin{array}{l}\text { Electrotechnics, Engineering Mechanics, Theory of Machine and } \\
\text { Mechanisms, Physical optics, Probability Theory and Mathematical Statistics }\end{array}$ & 5 & \multirow[t]{2}{*}{19} \\
\hline & Practical courses & Electrical and Electronic Practice, Electronic Technique Experiment & 2 & \\
\hline \multirow[t]{2}{*}{3} & theoretical courses & $\begin{array}{l}\text { Linear Algebra, College Physics, Complex Function and Integral } \\
\text { Transforms, Electronic Technique }\end{array}$ & 4 & \multirow[t]{2}{*}{18} \\
\hline & Practical courses & College Physics Experiment, Engineering Training, Engineering Drawing, & 2 & \\
\hline \multirow[t]{2}{*}{2} & theoretical courses & $\begin{array}{l}\text { Engineering Drawing, Advanced Mathematics, College Physics, Computer } \\
\text { Basis And Program Design }\end{array}$ & 4 & \multirow[t]{2}{*}{19} \\
\hline & Practical courses & Laboring for Public Benefit, Computer Experiment & 2 & \\
\hline \multirow{2}{*}{1} & theoretical courses & Advanced Mathematics, Computer Basis And Program Design & 2 & \multirow{2}{*}{17} \\
\hline & Practical courses & Entrance Education and Military Training & 1 & \\
\hline
\end{tabular}




\section{THE ANALYSIS OVERLAPPING PROBLEM OF CURRICULUM}

There are two main reasons about the overlapping problem of curriculum, the first reason is knowledge convergence, the overlapping content is the basic knowledge of the course, it is needed for the course's systematic. For example the content of the instrument accuracy analysis in the course of Photoelectric Instrument Design, another similar example is the some knowledge in Theory of Machine and Mechanisms is introduction in Instrument Elements Designing. The second reason is interdisciplinary, some knowledge is described in different courses. The example is the knowledge about the optical source is taught in both courses which Applied Optics and Photoelectric Detection Technology. The main overlapping problem of curriculum as Fig.2.

Table 3. The main overlapping problem of curriculum

\begin{tabular}{|c|c|c|c|}
\hline Overlapping type & Course 1 & Course 2,3 & The main overlapping knowledge \\
\hline \multirow{6}{*}{$\begin{array}{l}\text { Knowledge } \\
\text { convergence }\end{array}$} & Engineering Drawing & CAD about Parts of Instruments & Application of AutoCAD \\
\hline & $\begin{array}{c}\text { Fundamentals of Interchangeability } \\
\text { and Measurement Technology }\end{array}$ & $\begin{array}{c}\text { Instrument Manufacturing } \\
\text { Technique }\end{array}$ & Size chain \\
\hline & $\begin{array}{l}\text { Theory of Machine and } \\
\text { Mechanisms }\end{array}$ & Instrument Elements Designing & Gear train \\
\hline & $\begin{array}{c}\text { Accuracy Analysis about } \\
\text { Instrument }\end{array}$ & Photoelectric Instrument Design, & $\begin{array}{c}\text { Accuracy analysis and design for } \\
\text { precision machinery }\end{array}$ \\
\hline & $\begin{array}{c}\text { Accuracy Analysis about } \\
\text { Instrument }\end{array}$ & Instrument Elements Designing & $\begin{array}{l}\text { Instrument Elements Designing } \\
\text { for Shafting, gear and screw drive }\end{array}$ \\
\hline & Instrument Elements Designing & $\begin{array}{c}\text { Optical Instrument Assembly } \\
\text { and Adjustment }\end{array}$ & gear and screw drive \\
\hline \multirow{3}{*}{ Interdisciplinary } & Sensors \& Testing Technology & $\begin{array}{c}\text { Photoelectric Detection } \\
\text { Technology }\end{array}$ & Photoelectric effect \\
\hline & Applied Optic & $\begin{array}{c}\text { Photoelectric Instrument } \\
\text { Design }\end{array}$ & Typical optical system \\
\hline & Applied Optic & $\begin{array}{l}\text { Photoelectric Detection } \\
\text { Technology }\end{array}$ & The basis photometry \\
\hline
\end{tabular}

\section{THE COURSES' GOAL AND THE LOGIC OF CURRICULUM}

The fundamental order of the courses can be get base on the courses' systemize. The main relation of the courses about the major of optical instrument design as Fig.4, It is the main line how the design capacity for photoelectric instrument is trained. It begin with the Engineering Drawing, then, the courses such as Engineering Mechanics, Theory of Machine and Mechanisms, Instrument Manufacturing Technique, Instrument Elements Designing, CAD about Parts of Instruments are set up in sequence, until Instrument Elements Designing is taught as a comprehensive course. During the main courses in the main line are taught, the electricity basic courses, the courses about sensor and detection technology, the courses about optics, the courses about accuracy theory are all be taught too. These courses are the basic knowledge for the students who are able to design the photoelectric instrument.

Base on the courses' systemize, we can make it clear which course should belong to that the different overlapping content. So we can forms the syllabus, and make the courses' education goal. 

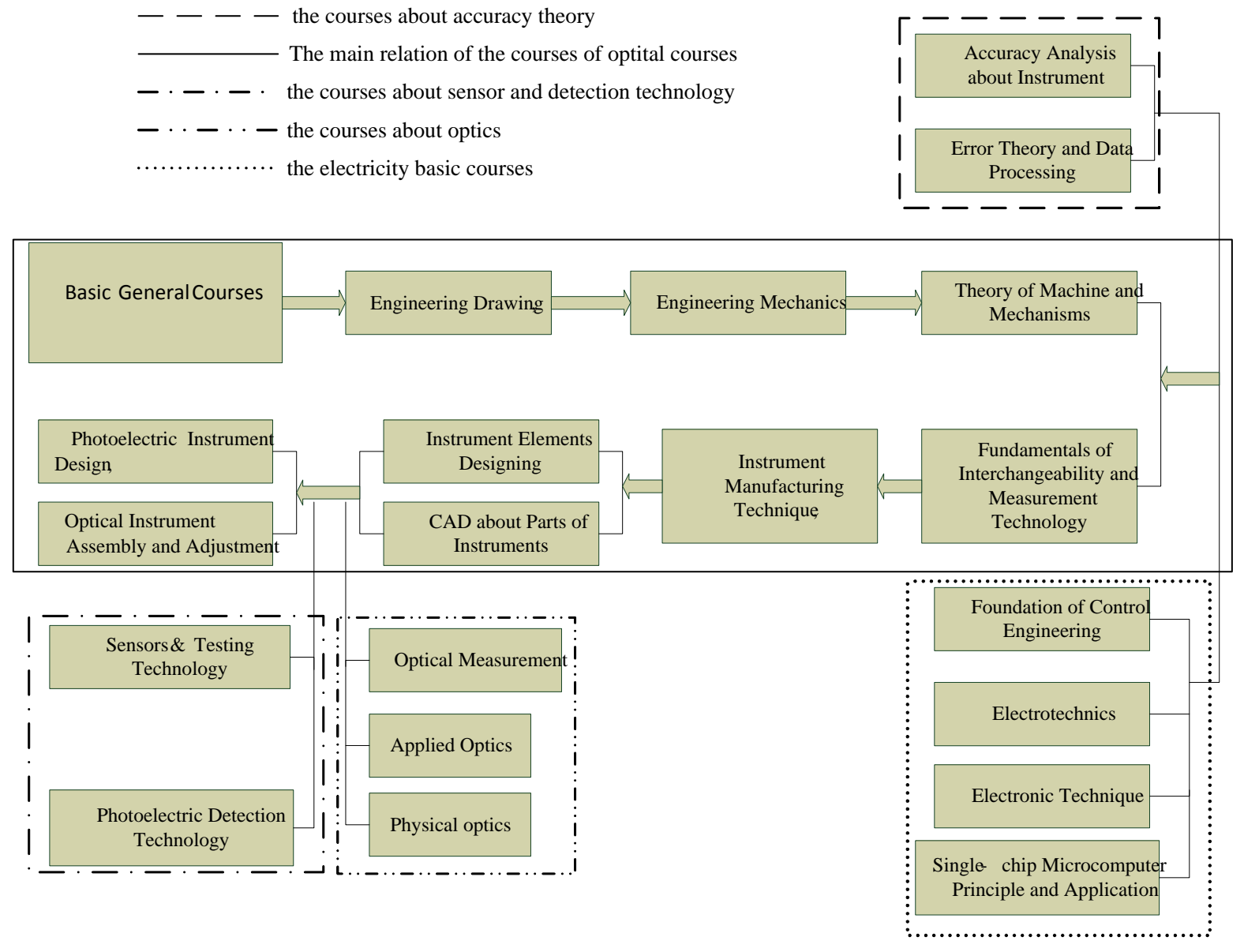

Figure 5. Relation of the courses about the major of optical instrument design

\section{CONCLUSION}

The main line and the order of the courses can be made clear through optimizing the curriculum system, these provide a basis of the course plan. Therefore, We conclude the overlapping problem of curriculum, and find it's reason, So the course objectives and syllabus are optimized accordingly.

\section{REFERENCES}

[1] Song Aiguo, Kuang Yinghui.The explore of talents training system of Measurement and Control Technology and Instrumentation[J]. Journal of Higher Engineering Education Research, 2005,(01):48-51.

[2] Yang Jun, Wang Guang-ming, Ye Xiang-bin. Exploration and Practice of Training Innovative Talents of Measurement and Control Technology and Instrumentation Specialty[J]. Journal of Higher Education Research, 2010,(02):14-16.

[3] Zhang Wen-na, Xiong Fei-li, Ye Xiang-bin, Luo Wu-sheng. Research on the integrated optimization of the specialized curriculum system of Measurement \&Control Technology and Instrument Specialty[J]. Journal of Higher Education Research, 2008,(02):33-35. 